DOI https://doi.org/10.18551/rjoas.2018-08.15

\title{
COLLABORATION VERSUS COORDINATION: A DILEMMA ABOUT STATE ACTORS' POSITION IN A POLICY
}

\author{
Mukhlis Maulana* \\ Government Department, Faculty of Social and Political Sciences, \\ University of Lampung, Indonesia
}

\author{
Suwaryo Utang, Deliarnoor Nandang Alamsah, Kartini Dede Sri, Rusli Budiman \\ Graduate Program, Faculty of Social and Political Sciences, \\ University of Padjajaran, Indonesia \\ *E-mail: maulanamukhlis1978@gmail.com
}

\begin{abstract}
This paper was composed regarding to the dilemma about the position and the role of the government in the collaborative governance along with its various logical consequences. In this context, the concept of coordination has a point of relevance. However, it was considered unnecessary for all involved parties to be bounded in a formal forum as the government was expected to act as a leader who holds the authority. The concept of collaboration might not be appropriate to be applied in any situation since the government needs to stabilize the public affairs of a nation in which the government should be given stronger position than non-government actors. In order to obtain better understanding about the dilemma related to government's position in the collaborative governance, some technical terms related to the issue of collaborative governance needed to be clarified.
\end{abstract}

\section{KEY WORDS}

Collaborative governance, dominance, coordination, public service.

A number of empirical studies put spotlight on the benefits and impacts of collaborative governance, showing that collaborative governance is an ideal approach to improve the quality of governance, public service and public policy performance (Innes, et al., 2006; Montero, 2006; Kim, 2010; Sranko, 2011; Vij, 2011; Zeppel, 2012; Gollagher and Janette, 2013; Indriati, 2015; Zaenuri, 2018). Literatures frame collaborative governance as an order that is often associated with good outputs and outcomes. The use of collaborative governance can increase the political legitimacy and significant level of public confidence in government performance amid government limitations in terms of resource capability, funding sources, and networks. The implementation of collaborative governance is able to significantly enhance the effects of political legitimacy and public trust toward the performance of government within a situation where resources, fund, and network are limited.

Henton in Susanti, (2016) highlighted the core of collaborative governance, namely (1) forum for public deliberation, (2) community problem solving, and (3) multi-stakeholders dispute resolution. Furthermore, they also explained the four main components in collaborative governance: consensus, joint vision, rules to evaluate certain decisions, and the organizational or institutional structure. The four components illustrate the need for collaboration forums that involve multi-stakeholders conduct interactive discussion based on multiple perspective in order to gain mutual understanding and obtain collective recommendations.

The forum is called the inter-organizational collaboration, involving the roles of the government, community or community actors, as well as the private sector for long periods of time and to solve general problems. Balogh, et al, (2011) asserted that collaborative governance does not only apply to stakeholders that consist of government and nongovernment actors, but it also forms the "multi-partner governance" covering private sector, 
society and civil society. Balogh, et all, (2011) stated that: "the processes and structures of public policy decision making and management that engage people constructively across the boundaries of public agencies, levels of government, and/or the public, private and civic spheres in order to carry out a public purpose that could not otherwise be accomplished".

Meanwhile, Robertson and Choi in Kumorotomo, (2013) define collaborative governance as a collective and egalitarian process in which each participant possesses substantial authority in decision-making process. Besides, every stakeholder has equal opportunity to speak up and share any idea. This concept has been put into written rule, giving each collaborating party equal position and opportunity to collaboratively involve in the process of public policy formulation and implementation.

In a broader framework, the above argument indicates the importance of collaborative governance as a model that allows intensive interaction among actors within good governance system, i.e. a nation, business, and society, especially in the implementation of public policy. Moreover, collaborative governance enables collaboration of those three actors within institutionalized forums, rules and collective agreements, besides it enhances the principle of equality. The keywords of equal position and opportunity in the process of public policy-making are aligned with the concept of governance as "the exercise of political power to manage a nation's affair" which is a starting point in understanding governance.

Those conceptual backgrounds eventually tap on these aspects, (i). Implementation of collaborative governance, in which formal forum should be deliberately formed as a forum that facilitates the ongoing process and accomplishment of a common consensus, and (ii) the achievement of a common consensus should be built upon equal opportunity, equality, and strength among the collaborating actors. However, Rahardja (2008) states that although the government is one of the actors in the collaboration forum and thus has equal alignment and strength with other actors, the government still has the authority and privilege to set certain regulation which authority is not owned by other actors.

In this context, the dilemma arises. In one side, the government has the authority and function to rule as the representative of the public, yet in the other hand, the government must compromise its authority as the member of the collaboration forum to implement the principle. A problem then appears, questioning on how to come up to the equal point of the roles without violating the alignment and the authority. The question is strongly relevant because Syafrudin (1976) also states that even though the government has equal authority, the government should lead the formulation process and policy implementation, whether or not the policy involves non-government parties. The dilemma in finding the balance between collaboration and coordination is the main point of this paper.

Collaboration versus Coordination. This section discusses the similarities and differences between collaborative terms with other equivalent terms, ie partnership, network, coordination, and cooperation. Various literatures see those terms as an answer to the problems that arise regarding to the concept of good governance which is expected to put emphasizes on the principles of participatory, transparency, accountability, rule of law, and responsiveness. Those terms share general meaning, yet it is considered important to analyze the different meanings of those terms in certain context.

The first term is partnership. In a simple way, partnerships refer to the collaboration between two organizations that collect and pool resources to pursue common goals. Etymologically, the word partnership is derived from the word partner. Partner can relate to "spouse, soul mate, ally or companion". Then the word partnership also relates to fellowship. Sulistiyani (2004) defines partnership as a form of relationship between two parties that forms a cooperative bond on the basis of agreement and mutual need to increase the capacity and capability in a particular field of business or a particular purpose in order to obtain better outcome. The concept of partnership is more often used in business context to obtain economic benefits.

The second term is network. The term network refers to the inter-organization system that is the developed based on traditional intra-organization theory. Furthermore, the term network is also used in program implementation theory proposed by Cheema and Roddineli in Subarsono (2005). They asserted that, the success of public policy implementation 
depends on networks adequacy and effectiveness in supporting the implementation of the program. This shows the importance of network in a policy, especially in the policy implementation.

The third difference relates to the fact that collaboration involves power and coercion, the ability to target certain results and to set certain preferences on others using their obedience and participation. Fifth, collaboration also involves future commitments and intentions, attitude, planning and preparation to align the activities. Sixth, collaboration improves the engagement, internal motivation, and personal commitment to held various activities, decisions, organizational goals or more strategic objectives. However, Wanna (2008) asserts that the six definition of collaboration are broader than the concept of coordination, which can be optimally selected when the awareness of actors to engage themselves in a good collaboration appears out of their consciousness.

Within this particular context, Syafrudin (1976) has actually asserted that coordination or any terminology equivalent to coordination matters if there is a leader in charge. Appointing non-government parties to take the lead raises the risks of losing the public interest as private sectors are profit oriented. Thus, state actors should lead the process because state actor is the only party that has the authority to control the process and the motives of a policy. However, appointing state actors to take lead opens up the opportunities for dominance, whereas dominance is something to avoid within collaboration.

The plan to move the central government to Lampung Province is a unique case regarding to the fact that government holds the authority as a leader. However, as the success of program implementation depends on land acquisition from private parties, then the authority owned by the state is not absolute and it is no longer the determinant of the implementation success. As the implication, the alignment of positions among actors prevails, but the dominance remains because state actors are regulators.

Consequently, the interaction within this system tends to be vulnerable to personal conflict of interests or institutional interests by the name of collaboration. This collaboration model can be employed only as a tactic to use the available opportunities to obtain personal interests. This is a clear example of how collaborative governance faces various challenges and dilemmas, especially in Indonesia, which governance is rather traditional.

The fourth terms are coordination, cooperation and collaboration. O'Flynn and Wanna (2008) believe that three equally refers to the mechanism or step to achieve goals within certain transformation process that begins with coordination to form collaboration. Those terms distinguish the term commands. Furthermore, they explained that command refers to the centralized process of control within certain hierarchical authority lines, then it is proceeded or transformed into coordination which refers to collective decision-making processes among participating institutions. Cooperation is a process of ideas and resources sharing for mutual benefit. Collaboration is also defined as the process of creating shared goals that are mediated or facilitated by independent institutions / institutions.

The terms coordination, cooperation, and collaboration together refers to the mechanisms for decision making and mutual goal determination among participating actors. However, to emphasize the role of the government as an authoritative and autonomous institution, the term collaboration is more appropriate when it is associated with research topics on governance, which eventually leads to the term collaborative governance.

Table 1 - The Transformation of Process

\begin{tabular}{|l|l|}
\hline Command & The process of centralized control - with clear lines of hierarchical authority \\
\hline Coordination & The process of collective decision making - imposed on participating institutions \\
\hline Cooperation & The process of sharing ideas and resources - for mutual benefit \\
\hline Collaboration & The process of shared creation - brokered between autonomous institutions \\
\hline
\end{tabular}

Source: O'Flynn and Wanna (2008).

In addition to the transformation of collaboration process as explained by Flynn and Wanna (2008), several researchers also take into account the explanation of the terms collaboration and partnership. Bovaird in Zaenuri, (2018) defines partnership as an arranged 
work that is designed based on reciprocal commitments beyond the contract made between public organizations and organizations outside the public sector. Likewise Munro (2008) sees partnership as a form of cooperation between community leaders and public managers to enhance the effectiveness of democracy. It is practically difficult to distinguish those two approaches (collaborative and partnership). Then, Cooper (2006) generally calls it a citizencentered governance.

The explanation above clearly shows that collaboration essentially has broader meaning beyond coordination, partnership, or cooperation. One of the fundamental differences is that collaboration involves power and coercion, rights to determine certain results or impose certain preferences using others' compliance or involvement in the forum.

Equality and Dominance of Actors within Collaboration. One of the keys to successful collaborative governance is the facilitation of leadership, in addition to initial conditions and inclusive institutional design that strictly regulates the rules of collaboration, Ansell and Gash, (2007). Next, one of the core facets of leadership facilitation is that the collaborative process will be strongly determined by the presence of key actors in taking the control (guarantee that collaboration will work according to the roles) of the collaborative process. Mandell \& Keist, in Wargadinata, (2015).

Along with the risk of tension arising from social dynamics in the collaboration forum, the role of power is also seen as an important challenge in collaborative governance. This means the term 'control' formal power structure within a collaboration forum cannot be interpreted as domination if rules strictly apply. The power of state actors exists or arises together simultaneously with the power dynamic social communication that involves other actors. Nevertheless, the formal authority or discursive authority, resources, and legitimacy can be challenging if they dominate both parties in determining the role, meaning, practice and outcome of collaboration (Plotnikof, 2015)

In general, the existence of formal structural domination of power is characterized by several aspects: (i) The control upon top-down mechanism by the government in establishing collaboration with other parties; (ii) The presence of government's dominance in controlling the process and outcomes; (iii) Violation upon mutual consensus based on cooperation and egalitarian. Collaboration might fail if the actors do not give adequate participations, causing dominance of certain actor over the others, which eventually leads to misalignment.

In relation to the parallel relationship among actors, Ansell and Gash (2007) added that there some other related to the interdependence among collaborators. Interdependence is seen as a logical consequence or expression of differences in the level of power and resources among actors (Gray, 1989). Interdependence is actually a prerequisite for the emergence of collaboration which at the same time might trigger conflicts if it is not properly managed. Strong dependency among collaborators lessens the possibility of conflict since one's interests can only be achieved through strong dependency. This dependency will grow stronger collaboration among actors. However, Gray (1989) highlights that if interdependence arises from apathy over some actors' dominances, the interdependence will give negative impacts on collaboration process.

Power Dominance in Collaboration. The notion of collaboration versus coordination triggers another dilemma as clearly shown in the case of the plan to move the center of the governance of Lampung Province, Indonesia. Due to entangled problems in city, the government of Lampung province lead by Sjachroedin ZP governor in 2007 planned to move the center of municipal governance of the province by establishing a new city in Jati Agung Sub-district, South Lampung. Ever since the issuance, the plan to move the center of municipal governance (sub target) and to establish a new city 9final target) has been designed to employ a collaborative governance.

This case makes a good example of collaborative governance concept as proposed by Ansell and Gash (2007). The governor of Lampung Province involved the participation of non-government parties and the society. Various decisions in the process were taken on the basis of collaboration and role distribution among participating actors. Formal coordination in the project was done in formal forum meeting attended by Tim Koordinasi Perencanaan or the Coordination and Planning Team dan Badan Pengelola Kawasan or the Management of 
the Site, which meeting has reached a mutual consessus written in Regional Regulation Number 2 of 2013 about Bandar Lampung City and the plan to move the center of municipal governance should be implemented based on collaboration among actors. Activities which have been conducted ever since the formulation and the implementation of this policy as seen from the view proposed by Emerson in Ulibarri (2015) show that the collaboration among actors in the policy has resulted in various outcome, agreement, and actions which become the core of the process and the main element of the general framework of the collaboration system.

The implementation of the policy to move the center of municipal governance was followed by power dominance and unequal power distribution among actors as well as among formal structural holders even between the state and other actors (non-government actors). The success of collaboration is strongly determined by the presence of a major actor that "controls" the collaboration process. Furthermore, even though coordination and planning team and management team had been appointed to facilitate formal forum for collaboration process, in fact, some institutions and the governor himself intervened and controlled the process themselves. This phenomena becomes an important issue to discuss as it disrupted the principle of equality among actors and the need to eliminate interdependence among actors within a collaboration. The fact shows that some actors dominated the process and interdependence among actors was massive. Gray (1989) asserts that the level of interdependence among actors determines the success of a collaboration process. Unfortunately, in the collaboration to move the center of municipal governance of Lampung province, this essential point did not occur.

During the implementation of the policy, the governor showed his dominance. Starting from the planning of the idea in the form of a revised Urban Planning (RT/RT) in 2007 up to the determination of targets in 2014, all activities of Lampung Province government has been moved to the new city of municipal governance center. Due to the rush in designing te Regional Regulation number 13 of 2007, some stakeholders that represented regional public interest and private interest were not involved in the discussion process. The governor then asserted that the rush was not any political movement from of certain interest since it occurred due to the need for the policy to have legal basis immediately as it was a strategic policy.

Dominance. The case study shows that dominance might result in inequality which might lead to distrust. Whereas in the long run, distrust is the source of conflict. Thompson in Rahim, (2001), argues that conflict in collaboration arises from differences in perceptions among people whose interests cannot be reconciled due to strong distrust in collaboration.

In addition to the domination of the government in the perspective of structural domination, the dominance of actors in the policy of moving the center of municipal governance of Lampung Province, function domination also occurred. Structural dominance is perceived as actors' authority or government formal authority to facilitate various transfers of resources as well as incentives. Meanwhile, functional dominance refers to substantial control authority and rationale of certain policy made by certain actors which lead to mutual understanding and agreement upon the rationale and objectives of certain policy that finally bound them into collaboration.

In this context, actors' dominance is a challenge for collaborative governance in coming to an ambivalence. Theoretically, the dominance of one actor should be avoided as it might inhibit collaboration. In fact, actors' dominance often provides benefits if is not perceived as an intervention towards other actors. Instead, it is rather seen as extra role given to other actors since they have superior ability and resources to manage the ongoing collaboration process.

Coordination and Quasi Collaboration. The view that certain actor's dominance might appear as a risk that leads to collaboration failure if it is not appropriately perceived and comprehended. This section briefly discusses whether coordination is the answer of problems related to power dominance in collaboration. The discussion above describes that the practice of both approaches (collaboration and coordination) is very difficult to 
distinguish. In a general context, Cooper (2006) calls both of them as models of governance based on the role of citizens (citizen-centered governance).

Bovaird and Munro in Zaenuri, (2018) call collaboration as an institutionalized partnership, but those two concepts basically have quite fundamental differences. Partnership is different from collaboration, because collaboration covers a broader scope than partnership. According to Wildavsky, as quoted by Wanna (2008), collaboration involves several different dimensions. First, collaboration can involve cooperation to build common interest, enhance consistency, and align activities among actors. Second, collaboration also refers to the negotiation process that involves readiness to compromise and form trade-offs. Third, collaboration includes supervision, inspection, decision making and central coordination in the forum.

Conclusion. Collaborative governance refers to strategies used in the implementation of public policy to achieve good outputs and outcomes. In the perspective of governance, collaborative governance is also way implement good governance when the concept of good governance is often accused to prioritize certain principles without offering feasible strategy. Collaborative governance is believed to consist of series of firm and measurable work patterns that allow open communication and build mutual consensus between the government and society as well as other non-government actors in certain governance and implementation of certain public policy.

Unfortunately, the implementation of ideal collaborative governance is rather challenging in Indonesia. The major challenge is often triggered by unequal dominance of certain actors over the others. The government as one of the actors also triggers this challenge as the government holds the authority to regulate and intervene the process. The principle of equality and in collaboration forums is not something that can be easily enforced. In more severe cases, 'flirting' actions often done by state actors and private actors as the ones that hold the authority to determine the direction and alignment governance which often beat the role of the community / community actors. Moreover, the role of the state is often weaker than the one of private sector in various policy implementation in Indonesia due to the availability of opportunities and the principles of equality itself.

Therefore, the implementation of collaborative governance is not a feasible strategy to be applied in every situation. However, the dominance of state actors over non-state actors is reasonable because each party has the rights over authority, while the principle of equal role alignment triggers risks which may eliminate the arranged authority distribution. The authority that regulates the involvement of foreign actors is called coordination. Coordination allows the state to continue involving non-government actors under the authority of the state as the leader.

In this context, it is important to note that in Indonesia, coordination is considered more appropriate to implement as it facilitates the implementation of public policy in which the government is involved. The dominance of the state actors should not be seen as unequal distribution of power, instead it should be seen as the entity of the authority.

Probably, collaborative governance might be the last option to use if a policy demands participation of non-government actors as major determinants to the success of the policy implementation. In the other word, collaborative governance is preferred if the government could not give adequate guarantee upon the success of certain policy implementation. Finally, the use of either collaboration or coordination system in the implementation of certain policy should be determined based on comprehensive understanding of the policy itself.

\section{REFERENCES}

1. Ansell, C. \& Gash, A. (2007). Collaborative Governance in Theory and Practice. Journal of Public Administration Research and Theory. Oxford University Press.(18), p. 543-571.

2. Balogh, S., Emerson, K., \& Nabatchi, T. (2011). An Integrative Framework for Collaborative Governance. Journal of Public Administration Research and Theory. Oxford University (5) Press. p. 1-30. 
3. Gray, B. (1989). Collaborating: Finding Common Ground for Multiparty Problems. San Francisco, CA: Jossey-Bass.

4. Indriati, J. (2015). Kolaborasi Dalam Pembangunan Daerah Di Jawa Barat (Studi Kontribudi CSR Bidang Kesehatan Dan Pendidikan). Disertasi Doktor IImu Administrasi Universitas Padjadjaran. Bandung: Program Pascasarjana FISIP Universitas Padjadjaran.

5. Innes, J.E., Connick, S., \& Kaplan, L. (2006). Collaborative Governance in the CALFED Program: Adaptive Policy Making for California Water. Working Paper Institute of Urban and Regional Development \& University of California Berkeley. From https://escholarship.org/content/qt48p87363/qt48p87363.pdf. On July 30th 2018

6. Kim, S. (2010). Collaborative Governance In South Korea: Citizen Partisipation in Policy Making and Welfare Service Provision. Journal of Asian Perspektif .Vol 34, No. 3. p. 337.

7. Kumorotomo, W. (2013). Transformasi Pelayanan Jakarta Commuter Line: Studi Tentang Collaborative Governance di Sektor Publik. Yogyakarta: Jurusan Manajemen dan Kebijakan Publik FISIPOL Universitas Gadjah Mada.

8. Munro, D.J.F. (2008). Motivation and Culture Government. Article p. 56. New York: New York Routledge.

9. O'Flynn, J \& Wanna, J. (2008). Collaborative Governance, A New Era of Public Policy in Australia?. Canberra: The Australian National University

10. Plotnikof, M (2015). Challenges of Collaborative Governance: An Organizational Discourse Study of Public Managers' Struggles with Collaboration across the Daycare Area. PhD Series 26.2015. Copenhagen, Denmark: Copenhegen Business School.

11. Raharja, S.D. (2008). Pendekatan Kolaboratif Dalam Pengelolaan Daerah Aliran Sungai Citarum. Disertasi Doktor IImu Administrasi Universitas Indonesia. Jakarta: Program Pascasarjana Universitas Indonesia.

12. Rahim, A. (2001). Managing Conflict in Organizations. London: Quorum Books.

13. Sergio, G.M. (2006). Collaborative Governance for Sustainable Water Resources Management: The Experience of the Inter-Municipal Initiative for the IIntegrated Management of the Aquila River Basin Mexico. Journal of Environmental \& Urbanization Vol 18(2). Published by International Institute for Environmental and Development (IIID). p. 297-313.

14. Sranko, G.R. (2011). Collaborative Governance and A Strategic Approach to Faciliting Change: Lesson Learned from Forest Agreement in South East Queensland and the Great Bear Rainforest. A Journal for and About Social Movement Vol. 3 (1). p. 210-239.

15. Subarsono, A. (2005). Analisis Kebijakan Publik Konsep, Teori, dan Aplikasi. Yogyakarta: Pustaka Pelajar.

16. Sulistiyani, A.T. (2004). Kemitraan dan Model-Model Pemberdayaan. Yogyakarta: Gava Media.

17. Susanti, E. (2016). Kolaborasi Dalam Penetapan Upah Minimum Di Kabupaten Bandung. Dissertation. Bandung: Program Pascasarjana FISIP Universitas Padjadjaran.

18. Syafrudin, A. (1976). Pengaturan Koordinasi Pemerintahan di Daerah. Bandung: Tarsito.

19. Ulibarri, N. (2015). Tracing Process to Performance of Collaborative Governance: A Comparative Case Study of Federal Hydropower Licensing. Journal Political Studies Volume 43 Issue 2. p. 283-308.

20. Vij, N. (2011). Collaborative Governance: Analysing Social Audits in MGNREGA in India. Bulletin Vol. 42 Number 6 November 2011. Published by Institute of Development Studies (IDS) Oxford.

21. Wargadinata, E. (2015). Kepemimpinan Kolaboratif. Jurnal Administrasi Pemerintahan Daerah Volume VIII(1): 1-14

22. Zaenuri, M. (2018). Tata Kelola Pariwisata Bencana Berbasis Collaborative Governance. Yogyarakta: Explore. 